\title{
CHIŃSKI KONSTYTUCJONALIZM - NAJNOWSZE ZMIANY W KONSTYTUCJI CHIŃSKIEJ REPUBLIKI LUDOWEJ
}

\author{
Konstytucja Chińskiej Republiki Ludowej ${ }^{1}$ \\ i jej dotychczasowe zmiany
}

\begin{abstract}
Obecnie obowiązująca Konstytucja Chińskiej Republiki Ludowej została przyjęta na piątej sesji V Ogólnochińskiego Zgromadzenia Przedstawicieli Ludowych (OZPL) i ogłoszona do realizacji przez obwieszczenie Ogólnochińskiego Zgromadzenia Przedstawicieli Ludowych w dniu 4 grudnia 1982 r. Konstytucja ChRL do marca 2018 r. była już czterokrotnie zmieniana, zgodnie z poprawkami przyjętymi na: pierwszej sesji VII Ogólnochińskiego Zgromadzenia Przedstawicieli Ludowych w dniu 12 kwietnia 1988 r., na pierwszej sesji VIII Ogólnochińskiego Zgromadzenia Przedstawicieli Ludowych w dniu 29 marca 1993 r., na drugiej sesji IX Ogólnochińskiego Zgromadzenia Przedstawicieli Ludowych w dniu 15 marca 1999 r. oraz na drugiej sesji X Ogólnochińskiego Zgromadzenia Przedstawicieli Ludowych w dniu 14 marca 2004 r. (łącznie wprowadzono 31 poprawek)².
\end{abstract}

1 Konstytucja ChRL w brzmieniu do 11 marca 2018 r. zob. Wu Lan, M. Dargas, Konstytucja Chińskiej Republiki Ludowej, Gdańsk 2012.

2 Dążenia konstytucyjne Chin zostały zapoczątkowane przez rewolucję ximbai (od nazwy roku, w którym doszło do przewrotu) w latach 1911-1913. W jej wyniku obalono feudalne cesarstwo i proklamowano Republikę Chińska. Rozpoczęły się wówczas próby konstytucjonalizacji porządku prawnego. Między 1912 (koniec cesarstwa) a 1926 r. w Chinach powstało pięć konstytucji lub ich projektów. W 1931 r. została przyjęta Tymczasowa konstytucja okresu politycznej opieki. Zgodnie z nią najwyższą władzą w Chinach miało być Zgromadzenie Narodowe Kongresu Partii Narodowej. Kolejne projekty Konstytucji Republiki Chińskiej pojawiły się w latach 1934 i 1936. Na czas wojny z Japonia procesy ustrojowe zostały zawieszone. W dniu 15 listopada 1946 r. w Nankinie, ówczesnej stolicy kraju, rozpoczęła się sesja Zgromadzenia Narodowego. Parlament 25 grudnia 1946 r. przyjął nową Konstytucję Republiki Chińskiej, która weszła w życie w 1947 r. W nowo proklamowanej Chińskiej Republice Ludowej (od 1949 r.) pierwszym aktem o charakterze konstytucyjnym był Wspólny program Ludowej Politycznej Rady Konsultatywnej Chin, przyjęty w trakcie sesji Rady Konsultatywnej w dniach 21-30 września 1949 r. W dniu 20 września 1954 r. przyjęto Konstytucję Chińskiej Republiki Ludowej oraz pięć podstawowych ustaw określających strukturę 
W nowelizacji z 12 kwietnia 1988 r. przyjęto 2 poprawki, tj. nowelizację art. 11, uznając sektor prywatny za uzupełnienie gospodarki opartej na systemie własności publicznej (wcześniej Konstytucja ChRL dopuszczała jedynie indywidualną działalność gospodarcza), a także zmiany do art. 10, w wyniku których dopuszczono obrót prawem użytkowania gruntów.

Nowelizacja z 29 marca 1993 r., wnosząca 9 poprawek, przyniosła doniosłe zmiany. W preambule Konstytucji ChRL zawarto obowiązek narodu wytrwania w reformach i otwarciu na świat, wprowadzono pojęcie socjalizmu o chińskiej specyfice oraz zaznaczono, że "Chiny znajdują się obecnie w początkowej fazie budowy socjalizmu”. Do preambuły dodano również zapis o „wielopartyjnym systemie współpracy i konsultacji politycznej pod przywództwem Komunistycznej Partii Chin”. Przyjęto system odpowiedzialności kontraktowej gospodarstw (art. 8) i wyeliminowano w ten sposób system własności kolektywnej socjalistycznych mas pracujących. Ponadto nowelizacja z 1993 r. wprowadziła socjalistyczna gospodarkę rynkowa jako podstawę systemu gospodarczego ChRL (art. 15). Uchylono zapis o obowiązku realizacji państwowych planów gospodarczych (art. 16 i 17). W odniesieniu do przedsiębiorstw i sektora gospodarki zastosowano pojęcie „państwowy” (国有 guóóóu) zamiast „zarządzany przez państwo”. Ponadto wydłużeniu uległa kadencja lokalnych zgromadzeń przedstawicieli ludowych z 3 do 5 lat.

Nowelizacja z 15 marca 1999 r. wprowadzono 6 kolejnych poprawek. Do preambuły dodano teorię Deng Xiaopinga jako jeden z elementów obowiązującej w ChRL ideologii, oprócz marksizmu-leninizmu i myśli Mao Zedonga. Ponadto doprecyzowano, że „początkowa faza budowy socjalizmu będzie trwać w Chinach przez długi czas". W art. 6 dodano zapis, że dopuszczalny jest rozwój różnych form własności i różne sposoby dystrybucji. Sektor prywatny, który do tej pory był tylko uzupełnieniem sektora państwowego, został uznany na mocy nowelizacji za ważną część składową chińskiej gospodarki (art. 11). Najbardziej doniosła w nowelizacji z 1999 r. była jednak zmiana art. 5. Zgodnie ze znowelizowanym przepisem ChRL jest socjalistycznym państwem prawnym realizującym rządy prawa. Również postanowienia konstytucyjne dotyczące porządku publicznego zostały zmienione, a mianowicie sformułowanie „działalność kontrrewolucyjna” zastapiono wyrażeniem „działalność zagrażająca bezpieczeństwu państwa” (art. 28).

W nowelizacji z 14 marca 2004 r. wprowadzono aż 14 poprawek. Do preambuły dodano kolejną, oprócz ideologii marksizmu-leninizmu, myśli Mao Zedonga

organizacyjną i zasady działalności Ogólnochińskiego Zgromadzenia Przedstawicieli Ludowych, Rady Państwowej (tj. rządu), terenowych organów władzy państwowej oraz sądownictwa i prokuratury. Następnie w 1975 r. znowelizowano tę konstytucję (w rzeczywistości konstytucja z 1975 r. tylko formalnie była nowelizacja konstytucji z 1954 r., bowiem w istocie była to całkowicie nowa konstytucja, zarówno „z litery prawa, jak i ducha”), by w dniu 5 marca 1978 r. przyjać kolejna ustawę zasadnicza. Szerzej zob. ibidem, s. 6-8. 
i teorii Deng Xiaopinga, ideę przewodnią narodu³ - ważną myśl Trzech Reprezentacji. Nałożono na lud obowiązek promocji skoordynowanego rozwoju cywilizacji w aspekcie materialnym, politycznym i duchowym. Państwo zostało zobowiązane do wypłaty odszkodowania za grunty przejmowane przez nie w związku z zaistnieniem interesu publicznego (art. 10). Ponadto objęto ochroną prawa interesy niepublicznego sektora gospodarki, a także nałożono na państwo obowiązek wsparcia i zachęty dla jego rozwoju (art. 11). Nowelizacja z 2004 r. wprowadziła również zasadę nienaruszalności prywatnego majątku obywatela (art. 13). Dodano zapis o obowiązywaniu systemu zabezpieczenia społecznego odpowiedniego do rozwoju gospodarczego (art. 14). Artykuł 33 został poszerzony o obowiązek poszanowania i ochrony praw człowieka przez państwo. Wprowadzono ponadto wiele zmian w przepisach konstytucyjnych dotyczących organów państwowych. W składzie OZPL mieli od tej chwili pojawić się również przedstawiciele specjalnych regionów administracyjnych (art. 59). Przyjęto pięcioletnie kadencje wszystkich zgromadzeń przedstawicieli ludowych (art. 98). Do zakresu kompetencji Przewodniczącego ChRL dodano sprawy państwowe (art. 81). Nowelizacja doprecyzowała, że stan wyjątkowy może zostać wprowadzony wyłącznie w granicach prawa (art. 67, 80, 89). Ostatnią zmianą w ramach tej nowelizacji było uznanie pieśni pt. Marsz Ochotnikón za oficjalny hymn ChRL (art. 136) ${ }^{4}$.

\section{Dotychczasowa treść Konstytucji Chińskiej Republiki Ludowej z dnia 4 grudnia 1982 r.}

Konstytucja Chińskiej Republiki Ludowej do 11 marca 2018 r. składała się z rozbudowanej preambuły i 138 artykułów podzielonych na 4 rozdziały: Zasady ogólne (I), Podstawowe prawa i obowiązki obywateli (II), Struktura państwa (III), Flaga, hymn, godło i stolica państwa (IV).

Rozbudowana preambuła Konstytucji ChRL przypomina wzniosłe wydarzenia w dziejach narodu chińskiego - dokonania, postaci, wskazując je jako przykład, a ich dorobek jako wzór do naśladowania. Zawiera elementy tradycji narodu oraz idee, zasady i wartości, na jakich ma się opierać państwo, a także wskazuje cele narodu i państwa. Chiny zostały określone jako kraj o jednej z najdłuższych historii na świecie. Zaakcentowano udział narodu w walkach o niepodległość, wyzwolenie, demokrację i wolność oraz chińską tradycję rewolucyjna. Wskazano, że po 1840 r. Chiny

3 W preambule Konstytucji ChRL znajduje się sformułowanie: ,kierując się wskazówkami ideologii marksizmu-leninizmu, a także myślą Mao Zedonga, teorią Deng Xiaopinga i ważną myślą Trzech Reprezentacji”". Określono tym samym idee przewodnie, którymi powinien kierować się chiński naród.

4 Wu Lan, M. Dargas, Wprowadzenie [w:] Konstytucja..., s. 5-11. 
rozpoczęły proces przekształcania w kraj półkolonialny i półfeudalny. Następnie zwrócono uwagę na przełomowe zmiany, jakie zaszły w XX wieku. Wśród nich wymieniono rewolucję z 1911 r., która obaliła feudalną monarchię. Zastrzeżono jednak, że misja narodu chińskiego, polegająca na obaleniu feudalizmu i imperializmu, nadal trwa. Odnotowano zmiany, jakie nastąpiły po powstaniu Republiki Chińskiej, przekształcanie nowej demokracji w społeczeństwo socjalistyczne. Wskazano na zmianę formy własności środków produkcji, które stały się własnością państwową („,socjalistyczne przekształcenie prywatnej własności środków produkcji zostało zakończone"), a także na ustanowienie systemu socjalistycznego. Ogólnikowo odwołano się do sukcesów gospodarczych i kulturalnych. Jako podstawowe zadania narodu na przyszłość wskazano budowanie socjalizmu o chińskiej specyfice oraz socjalistycznej modernizacji, zwracając uwagę na cztery główne ideologie, którymi powinien kierować się naród chiński: marksizm-leninizm, myśl Mao Zedonga, teoria Deng Xiaopinga, ważna myśl Trzech Reprezentacji.

Teoria Deng Xiaopinga odnosi się do czterech zasad kardynalnych (四项基本 原则 - sì xiàng jibèn yuánzę), tij. politycznego przywództwa KPCh, demokratycznej dyktatury ludu jako podstawy państwa, systemu ekonomicznego w postaci „drogi socjalistycznej” oraz kierowania się wskazówkami ideologii marksizmu-leninizmu i myśli Mao Zedonga. Ważna myśl Trzech Reprezentacji (三个代表 - sān gè dàibiăo) oznacza, że KPCh musi reprezentować najbardziej fundamentalne interesy większości ludu. Założenia tej teorii dotyczą umożliwienia aktywnego życia politycznego osobom, które reprezentuja: 1) rozwinięte siły produkcyjne, 2) siły postępowe zaangażowane w budowę wysokiej kultury, 3) KPCh, która reprezentuje podstawowe interesy większości.

Teoria Trzech Reprezentacji została w 2000 r. przedstawiona przez Jiang Zemina jako uzasadnienie legitymizacji KPCh jako partii rządzącej. Najważniejszym elementem tej teorii była zasada reprezentacji „fundamentalnych interesów większości narodu". Zgodnie z nią zadaniem partii jest reprezentacja potrzeb przodujących sił produkcyjnych, przodującej kultury oraz fundamentalnych interesów większości narodu. W dniu 1 lipca 2001 r. w swoim przemówieniu Jiang Zemin akcentował konieczność dostosowania doktryny marksizmu-leninizmu do chińskiej specyfiki. Hu Jintao - przewodniczący Chińskiej Republiki Ludowej w latach 2002-2012 oraz sekretarz generalny KPCh na XVII Zjeździe KPCh w 2007 r. wyjaśnił, że teoria socjalizmu o chińskiej specyfice obejmuje system naukowych teorii: Deng Xiaoopinga, ważną myśl Trzech Reprezentacji, naukowy światopogląd na rozwój oraz inne strategiczne teorie. System tych teorii obejmuje przestrzeganie przez partię zasad i rozwój marksizmu-leninizmu oraz myśli Mao Zedonga, jak również urzeczywistnia mądrość i ciężką pracę kilku pokoleń chińskich komunistów, prowadzących $\mathrm{i}$ wspierających obywateli w niestrudzonym odkrywaniu i praktyce.

Ostatnimi wskazanymi w preambule osiagnięciami są: przystosowanie marksizmu do chińskich warunków, polityczny i intelektualny wkład partii oraz wspólny 
ideologiczny fundament wysiłków ludzi wszystkich grup etnicznych. Xi Jinping, od 2012 r. przewodniczący ChRL, na XVIII Zjeździe KPCh w 2012 r., odnosząc się do socjalizmu o chińskiej specyfice, zwrócił uwagę, że „system socjalistyczny o specyfice chińskiej stał się fundamentalnym dokonaniem naszej partii i narodu osiagniętym w wyniku nieugiętej walki, tak jak miało to miejsce w ciagu minionych 90 lat i powinniśmy cenić to, co zostało już dokonane, a raczej starać się kontynuować i wzbogacać dotychczasowe dokonania" 5 .

We wstępie do Konstytucji ChRL zaakcentowano również potrzebę podejmowania działań na rzecz zjednoczenia Chin. Wymieniono Chińską Ludową Polityczną Radę Konsultatywna jako organizację odgrywającą bardzo istotną rolę w socjalistycznej modernizacji i zjednoczeniu kraju. W myśl preambuły system ChRL jest systemem wielopartyjnej współpracy i konsultacji politycznej. Wprost określono rolę przewodnią Komunistycznej Partii Chin. Wskazano na równość, jedność i wzajemność jako podstawę stosunków socjalistycznych. Określona została również niezależna pozycja Chin na arenie międzynarodowej, wskazano na zasady poszanowania suwerenności i integralności terytorialnej, wzajemnej nieagresji, wzajemnej nieingerencji w sprawy wewnętrzne, równości i wzajemności korzyści oraz pokojowego rozwijania stosunków dyplomatycznych, ekonomicznych i kulturalnych z innymi krajami. Ostatni paragraf preambuły zwraca uwagę na nadrzędną rolę Konstytucji ChRL w systemie źródeł prawa.

Rozdział I Konstytucji ChRL w art. 1-32 zawiera zasady ogólne chińskiego porządku prawnego. Chińska Republika Ludowa została określona jako socjalistyczne państwo demokratycznej dyktatury ludu, realizujące rządy prawa (art. 1 i 5). Cała władza w ChRL należy do ludu, który zarządza sprawami państwowymi, ekonomicznymi i kulturalnymi kraju za pośrednictwem OZPL i lokalnych zgromadzeń przedstawicieli ludowych (art. 2), a ich członkowie są wyłaniani w drodze wyborów. Organy państwowe ChRL realizują zasadę centralizmu demokratycznego (art. 3). W myśl art. 4 Konstytucji ChRL wszystkie grupy etniczne zamieszkujące terytorium ChRL są równe, a państwo wspiera tereny zamieszkałe przez mniejszościowe grupy etniczne; ponadto przepis ten przewiduje możliwość realizacji autonomii regionalnej przez poszczególne grupy etniczne.

Podstawa socjalistycznej gospodarki rynkowej ChRL (art. 15) jest socjalistyczna, społeczna własność produkcji - własność ogólnonarodowa i kolektywna własność ludu pracującego (art. 6), a wiodącą siłą w gospodarce narodowej jest gospodarka państwowa (art. 7). Konstytucja dopuszcza funkcjonowanie w ramach gospodarki narodowej: wiejskich kolektywnych organizacji gospodarczych (art. 8), indywidualnych, prywatnych i innych niepublicznych sektorów gospodarki (art. 11), przedsiębiorstw państwowych (art. 16), zbiorowych organizacji gospodarczych (art. 17), zagranicznych przedsiębiorstw i organizacji gospodarczych, zagranicznych osób

5 Xi Jinping, Innowacyjne Chiny, tłum. S. Szafarz, Warszawa 2015, s. 26. 
prywatnych, spółek joint venture (art. 18). Własność publiczna zgodnie z art. 12 jest „święta i nienaruszalna” (神圣不可侵犯 - shénshèng bùkě qinnàn). Własność państwa stanowią wszystkie grunty w miastach (art. 10) oraz wszelkie zasoby mineralne (art. 9). Grunty wiejskie i podmiejskie niestanowiące własności państwa stanowia własność kolektywów. Osobom prywatnym albo podmiotom gospodarczym może zostać przekazane prawo użytkowania określonych gruntów (art. 10). Państwo chroni własność prywatną obywateli. Dopuszczalne jest jednak dokonanie wywłaszczenia lub rekwizycji własności. W takim przypadku obywatelowi należy się odszkodowanie (art. 13).

Do obowiązków państwa należy rozwój edukacji i jej zapewnienie obywatelom ChRL (art. 19), wspieranie rozwoju nauki i upowszechnianie wiedzy naukowej (art. 20), rozwój usług medycznych (art. 21), promocja i wspieranie kultury (art. 22), szkolenie personelu (art. 23), budowanie socjalistycznej cywilizacji duchowej (精神文明, jingshén wénming, art. 24), promowanie planowania rodziny zgodnie z rozwojem społecznym i gospodarczym kraju (art. 25), ochrona i poprawa warunków życia ludu (art. 26). Organy państwa przy wykonywaniu zadań kieruja się zasada prostej i skutecznej administracji oraz mają obowiązek realizowania woli ludu (art. 27).

Konstytucja ChRL nakłada na państwo obowiązek utrzymywania porządku publicznego i zapewnienia bezpieczeństwa (art. 28). Do obrony narodowej powołane są Sily Zbrojne ChRL (art. 29).

Konstytucja określa podział administracyjny kraju. Zgodnie z jej art. 30 kraj jest podzielony na prowincje, regiony autonomiczne i miasta wydzielone podległe bezpośrednio rządowi centralnemu. Prowincje i regiony autonomiczne są podzielone na okręgi autonomiczne, autonomiczne powiaty, powiaty i miasta. Powiaty autonomiczne i powiaty sa podzielone na gminy, gminy narodowościowe i osiedla. Miasta wydzielone podległe bezpośrednio rządowi centralnemu są podzielone na dzielnice i powiaty. Okręgi autonomiczne sa podzielone na powiaty autonomiczne, powiaty i miasta. Wszystkie regiony autonomiczne, okręgi autonomiczne i powiaty autonomiczne wchodzą w skład etnicznych terenów autonomicznych. Konstytucja ChRL przewiduje możliwość tworzenia w miarę potrzeby specjalnych regionów administracyjnych, których ustrój określa w drodze ustawy OZPL (art. 31).

W art. 32 zawarto też obowiązek dbania o prawa i interesy cudzoziemców, którzy przebywają na terytorium Chin, a cudzoziemcy, którzy zwrócą się o azyl z powodów politycznych, moga go uzyskać.

Rozdział II Konstytucji ChRL określa podstawowe prawa i obowiązi obywateli, takie jak: równość wobec prawa (art. 33), bierne i czynne prawo wyborcze (art. 34), wolność słowa, prasy, zgromadzeń, stowarzyszeń, pochodów i demonstracji (art. 35), wolność wyznania (art. 36), wolność osobista (art. 37), godność osobista (art. 38), nienaruszalność miejsca zamieszkania (art. 39), wolność i prywatność korespondencji (art. 40), prawo do krytyki i sugestii w stosunku do or- 
ganów państwa, do wnoszenia skarg, zarzutów i donosów na działania organów państwa lub funkcjonariuszy, prawo do odszkodowania za szkody poniesione w związku z działaniami organów państwa (art. 41), prawo do pomocy materialnej ze strony państwa (art. 44, 45), prawo do edukacji (art. 46), swoboda prowadzenia badań naukowych, twórczości literackiej i artystycznej oraz innych zajęć kulturalnych (art. 47). Konstytucja ChRL przyznaje również prawo do pracy (art. 42) i odpoczynku (art. 43), prawo pracowników do emerytury (art. 44), prawo do równości płci (art. 48), prawo do ochrony małżeństwa, rodziny, matki i dziecka (art. 49), prawo do ochrony praw i interesów obywateli chińskich przebywających za granicą oraz praw i interesów obywateli chińskich powracających z zagranicy, a także członków rodzin chińskich obywateli mieszkających za granica (art. 50), cudzoziemcy maja prawo do azylu z powodów politycznych (art. 32, rozdz. I), oskarżeni maja prawo do obrony (art. 125, rozdz. II, dział 7), prawo do ochrony praw i interesów przedsiębiorstw zagranicznych, zagranicznych organizacji gospodarczych, spółek joint venture z chińskim i zagranicznym kapitałem mających siedzibę na terytorium Chin (art. 18, rozdz. I).

Wszystkie osoby posiadające obywatelstwo ChRL są obywatelami ChRL (art. 33 ust. 1). Każdy obywatel ma prawa i obowiązki określone w Konstytucji ChRL i ustawach (art. 33 ust. 2). Obywatele Chin, korzystając ze swoich wolności i praw, nie mogą naruszać interesów państwa, społeczeństwa i kolektywu lub legalnych praw i wolności innych obywateli (art. 51). Obywatele maja prawo do zabezpieczenia społecznego (art. 45).

Rozdział III Konstytucji ChRL określa strukturę organów państwowych. Dział 1 tego rozdziału stanowi, że najwyższym organem władzy państwowej jest Ogólnochińskie Zgromadzenie Przedstawicieli Ludowych, którego deputowani są wybierani przez zgromadzenia ludowe prowincji. Konstytucja przewiduje czterostopniową strukturę władzy (art. 95). Na najwyższym szczeblu znajduje się rząd centralny, prowincje (obejmujące miasta wydzielone podlegające bezpośrednio rządowi centralnemu i etniczne tereny autonomiczne), miasta i powiaty, gminy w ramach powiatów i dzielnice $w$ ramach miast.

W ostatnim, IV rozdziale Konstytucji ChRL w trzech artykułach określono wygląd flagi państwowej (art. 136) oraz godła państwowego (art. 137), wskazano, że hymnem Chińskiej Republiki Ludowej jest Marsz Ochotnikón (art. 136), a stolicą kraju Pekin (art. 138) ${ }^{6}$.

${ }^{6}$ M. Dargas, Idee i zasady konstytucyjne cbinskiego porzadku prawnego, Warszawa 2017, s. 137-142 i źródła tam wskazane. 


\section{Zmiany w Konstytucji ChRL w 2018 r.}

Najnowsza nowelizacja Konstytucji ChRL została uchwalona na pierwszej sesji XIII Ogólnochińskiego Zgromadzenia Przedstawicieli Ludowych w dniu 11 marca 2018 r. Wprowadzono następujące zmiany:

1. W siódmym akapicie preambuły do Konstytucji ChRL zdanie: „,kierując się wskazówkami ideologii marksizmu-leninizmu, a także myślą Mao Zedonga, teorią Deng Xiaopinga i ważną myślą Trzech Reprezentacji” zostało zmienione na: „,kierując się wskazówkami ideologii marksizmu-leninizmu, a także myślą Mao Zedonga, teorią Deng Xiaopinga i ważną myślą Trzech Reprezentacji, naukowymi perspektywami rozwoju i myśla Xi Jinpinga o socjalizmie o chińskiej specyfice dla nowej ery"; sformułowanie „umacniać socjalistyczną praworządność” zostało zmienione na: „umacniać socjalistyczne rządy prawa”; przed sformułowaniem „pracować ciężko i polegając na sobie samych” dodano „stosując nową wizję rozwoju”; „promować skoordynowany rozwój cywilizacji w aspekcie materialnym, politycznym i duchowym, aby przemienić Chiny w państwo socjalistyczne, które jest zamożne, silne, demokratycznie i kulturowo rozwinięte” zmieniono na: „promować skoordynowany rozwój cywilizacji w aspekcie materialnym, politycznym, duchowym, społecznym oraz ekologicznym, aby przemienić Chiny w silne współczesne państwo socjalistyczne, które jest zamożne, demokratyczne, kulturowo rozwinięte, harmonijne i piękne, i aby osiagnać wielkie odrodzenie narodu chińskiego (中华民族伟大复兴 Zhōnghuá mínzú wèidà fùxing)".

Cały zmieniony paragraf brzmi: „Zarówno zwycięstwo chińskiej nowodemokratycznej rewolucji, jak i sukces sprawy socjalizmu zostały osiagnięte przez przedstawicieli wszystkich chińskich grup etnicznych pod przewodnictwem Komunistycznej Partii Chin, kierując się wskazówkami ideologii marksizmu-leninizmu oraz myślami Mao Zedonga, dzięki popieraniu prawdy, naprawianiu błędów, a także przezwyciężaniu licznych problemów i trudności (多艰难险阻而取得的 - duō jiännán xiăñŭ ér qŭ́dé de).

Chiny będa pozostawać w początkowym okresie socjalizmu przez długi czas. Podstawowym zadaniem narodu jest skoncentrowanie swoich wysiłków na socjalistycznej modernizacji, podążając drogą budowy socjalizmu o chińskiej specyfice pod przewodnictwem Komunistycznej Partii Chin oraz kierując się wskazówkami ideologii marksizmu-leninizmu, a także myślą Mao Zedonga, teorią Deng Xiaopinga i ważną myślą Trzech Reprezentacji, naukowymi perspektywami rozwoju i myślą Xi Jinpinga o socjalizmie o chińskiej specyfice dla nowej ery (习近 平新时代中国特色社会主义思想指引下 - X Xỉinping xin shídäi zhbōngguó tèsè shèbui

Tekst nowelizacji Konstytucji ChRL dostępny jest na stronach OZPL: http://www.npc.gov. cn/npc/xinwen/201803/12/content_2049190.htm (dostęp: 20.11.2018). 


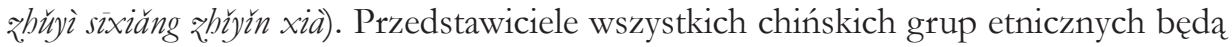
kontynuować dostosowywanie się do demokratycznej dyktatury ludu i drogi socjalistycznej, nie będa ustawać w reformach i otwieraniu się na świat zewnętrzny, będą stale doskonalić instytucje socjalistyczne, rozwijać socjalistyczną gospodarkę rynkową i demokrację socjalistyczną oraz umacniać socjalistyczne rządy prawa, stosując nową wizję rozwoju (健全社会主义法治, 贯彻新发展理念 - iànquán

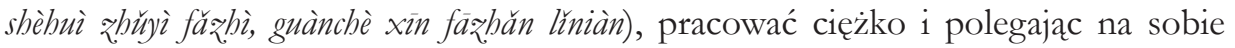
samych, aby stopniowo modernizować krajowy przemysł, rolnictwo, obronność narodowa, naukę i technologię, a także promować skoordynowany rozwój cywilizacji w aspekcie materialnym, politycznym, duchowym, społecznym oraz ekologicznym, aby przemienić Chiny w silne nowoczesne państwo socjalistyczne, które jest zamożne, demokratyczne, kulturowo rozwinięte, harmonijne i piękne, i aby osiągnąć wielkie odrodzenie narodu chińskiego".

2. W dziesiatym akapicie preambuły Konstytucji: „w trakcie długich lat rewolucji i budowy państwa” zmieniono na: „, w trakcie długich lat rewolucji, budowy państwa i reform”; „składajacy się z partii demokratycznych i organizacji ludowych, zrzeszający cały socjalistyczny lud pracujący, wszystkich patriotów wspierających socjalizm oraz wszystkich patriotów, którzy popierają zjednoczenie ojczyzny" zmieniono na: „składający się z partii demokratycznych i organizacji ludowych, zrzeszający cały socjalistyczny lud pracujący, wszystkich patriotów wspierających socjalizm oraz wszystkich patriotów, którzy popierają zjednoczenie ojczyzny i dążą do odrodzenia narodu chińskiego".

Cały paragraf otrzymał następujące brzmienie: „W budowaniu socjalizmu konieczne jest poleganie na robotnikach, chłopach i inteligencji oraz zjednoczenie wszystkich sił, jakie mogą zostać zjednoczone. W trakcie długich lat rewolucji, budowy państwa i reform pod przewodnictwem Komunistycznej Partii Chin został utworzony silny zjednoczony front patriotyczny, składający się z partii demokratycznych i organizacji ludowych, zrzeszający cały socjalistyczny lud pracujący, wszystkich patriotów wspierających socjalizm oraz wszystkich patriotów, którzy popieraja zjednoczenie ojczyzny i dążą do odrodzenia narodu chińskiego. Ten zjednoczony front będzie nadal wzmacniany i rozwijany. Chińska Ludowa Polityczna Rada Konsultatywna, organizacja reprezentująca zjednoczony front, która odegrała znaczącą historyczną rolę, będzie odgrywać jeszcze ważniejszą rolę w życiu politycznym i społecznym kraju, popierać przyjaźń z innymi krajami w walce o socjalistyczną modernizację, zjednoczenie i jedność kraju. System wielopartyjnej współpracy i konsultacji politycznej pod kierownictwem Komunistycznej Partii Chin będzie istnieć i rozwijać się przez długi czas".

3. W jedenastym akapicie preambuły zdanie: „Socjalistyczne stosunki oparte na równości, jedności i wzajemności zostały nawiązane pomiędzy wszystkimi grupami 
etnicznymi i nadal będą wzmacniane” zostało zmienione na: „Socjalistyczne stosunki oparte na równości, jedności, wzajemności i harmonii (谐的 - xié de) zostały nawiązane pomiędzy wszystkimi grupami etnicznymi i nadal będą wzmacniane".

4. W dwunastym akapicie preambuły zmieniono zdanie „Osiagnięcia Chin w rewolucji i budowaniu (państwa socjalistycznego - przyp. tłum.) są nierozerwalnie związane ze wsparciem narodów świata” na następujące: „Osiagnięcia Chin w rewolucji, budowaniu i reformach są nierozerwalnie związane ze wsparciem narodów świata”; po zdaniu: „Chiny konsekwentnie realizują niezależna politykę zagraniczną i trzymaja się pięciu zasad: wzajemnego poszanowania suwerenności i integralności terytorialnej, wzajemnej nieagresji, wzajemnej nieingerencji w sprawy wewnętrzne, równości i wzajemności korzyści, pokojowego wspólistnienia” dodano: „podążają ścieżką pokojowego rozwoju i dążą do wzajemnie korzystnej strategii otwarcia”; a także uzupełniono fragment: „w rozwijaniu stosunków dyplomatycznych oraz ekonomicznej i kulturalnej wymiany z innymi krajami”, dodając zaraz po słowach ,,innymi krajami”: „pracując nad budowaniem społeczności o wspólnej przyszłości dla ludzkości”.

Cały znowelizowany paragraf brzmi w następujący sposób: „Osiagnięcia Chin w rewolucji, budowaniu i reformach są nierozerwalnie związane ze wsparciem narodów świata. Przyszłość Chin jest ściśle związana z przyszłością całego świata. Chiny konsekwentnie realizują niezależną politykę zagraniczną i trzymają się pięciu zasad: wzajemnego poszanowania suwerenności i integralności terytorialnej, wzajemnej nieagresji, wzajemnej nieingerencji w sprawy wewnętrzne, równości i wzajemności korzyści, pokojowego współistnienia, podążając ścieżką pokojowego rozwoju i dążąc do wzajemnie korzystnej strategii otwarcia w rozwijaniu stosunków dyplomatycznych oraz ekonomicznej i kulturalnej wymiany z innymi krajami, pracując na rzecz budowy społeczności o wspólnej przyszłości dla ludzkości. Chiny konsekwentnie sprzeciwiają się imperializmowi, hegemonii i kolonializmowi, działają na rzecz umocnienia jedności z innymi narodami, wspieraja uciskane narody i kraje rozwijające się w ich sprawiedliwej walce o zwycięstwo i zachowanie niepodległości narodowej oraz rozwój narodowej gospodarki, dążą do zachowania pokoju na świecie, a także popierają postęp ludzkości”.

5. W art. 1 po zdaniu: „Ustrój socjalistyczny jest podstawowym ustrojem Chińskiej Republiki Ludowej” dodano: „Cechą definiująca socjalizm o chińskiej specyfice jest przywództwo Komunistycznej Partii Chin".

6. Ustęp 3 art. 3: „Wszystkie administracyjne, sądowe oraz prokuratorskie organy państwa sa powoływane przez lokalne zgromadzenia ludowe, wobec których sa odpowiedzialne i przez które są kontrolowane” zmieniono na: „Wszystkie admini-

8 Wu Lan, M. Dargas, Konstytucja..., s. 19. 
stracyjne, nadzorcze, sądowe oraz prokuratorskie organy państwa są powoływane przez lokalne zgromadzenia ludowe, wobec których są odpowiedzialne i przez które są kontrolowane".

7. Artykuł 4 ust. 1: „Państwo chroni prawa i interesy mniejszości narodowych oraz stoi na straży i rozwija stosunek równości, jedności i wzajemnego wsparcia pomiędzy grupami etnicznymi Chin” zmieniono na: „Państwo chroni prawa i interesy mniejszości narodowych oraz stoi na straży i rozwija stosunek równości, jedności, wzajemnego wsparcia $\mathbf{i}$ harmonii pomiędzy grupami etnicznymi Chin".

8. Artykuł 24 ust. 2: „Państwo popiera cnoty obywatelskie miłości do ojczyzny, do ludzi, do pracy, do nauki i do socjalizmu” zmieniono na: „Państwo wspiera podstawowe wartości socjalistyczne i popiera cnoty obywatelskie miłości do ojczyzny, do ludzi, do pracy, do nauki i do socjalizmu".

Cały zmieniony paragraf brzmi: „Państwo wspiera podstawowe wartości socjalistyczne i popiera cnoty obywatelskie miłości do ojczyzny, do ludzi, do pracy, do nauki i do socjalizmu. Prowadzi wychowanie wśród narodu w duchu patriotyzmu, kolektywizmu, internacjonalizmu i komunizmu, w duchu materializmu dialektycznego i historycznego, zwalczania kapitalistycznych, feudalnych i innych dekadenckich ideologii".

9. W art. 27 dodano ust. 3: „Funkcjonariusze państwowi składają publiczną przysięgę wierności Konstytucji przy obejmowaniu urzędu".

10. Ustęp 4 art. 65: „Nikt ze Stałego Komitetu Ogólnochińskiego Zgromadzenia Przedstawicieli Ludowych nie może pozostawać w służbie w organach administracji państwowej, organach sądowych ani w organach prokuratury” zmieniono na „Nikt ze Stałego Komitetu Ogólnochińskiego Zgromadzenia Przedstawicieli Ludowych nie może pozostawać w służbie w organach administracji państwowej, nadzoru, organach sądowych ani w organach prokuratury”.

11. Artykuł 67 pkt 6 określający funkcje i uprawnienia Stałego Komitetu Ogólnochińskiego Zgromadzenia Przedstawicieli Ludowych zmieniono na: „nadzorowanie prac Rady Państwowej, Centralnej Komisji Wojskowej, Państwowej Komisji Nadzoru, Najwyższego Sądu Ludowego oraz Najwyższej Prokuratury Ludowej”. Dodano pkt 11: „mianowanie i odwoływanie, na wniosek Przewodniczącego Państwowej Komisji Nadzoru, wiceprzewodniczących i członków Państwowej Komisji Nadzoru". Dotychczasowe punkty od 11 do 21 zyskały nową numerację od 12 do 22 .

12. Zmieniono również art. 79 ust. 3. Jego dotychczasowe brzmienie było następujące: „Kadencja Przewodniczącego i Wiceprzewodniczącego Chińskiej Republiki 
Ludowej jest taka sama jak Ogólnochińskiego Zgromadzenia Przedstawicieli Ludowych. Przewodniczący i Wiceprzewodniczący mogą piastować swoje stanowiska nie więcej niż dwie kolejne kadencje”. Nowelizacja zniosła ograniczenia, usuwając drugie zdanie tego ustępu, dotyczące kadencyjności urzędu Przewodniczącego i Wiceprzewodniczącego ChRL.

13. Artykuł 89 pkt 6: ,kieruje i zarządza sprawami gospodarczymi, rozwojem obszarów miejskich i wiejskich” został uzupełniony o sformułowanie: ,a także budowa cywilizacji ekologicznej” zyskał nowe brzmienie: „kieruje i zarządza sprawami gospodarczymi, rozwojem obszarów miejskich i wiejskich, a także budową cywilizacji ekologicznej”. Punkt 8 tego artykułu został zmieniony z „kieruje i zarządza sprawami cywilnymi, bezpieczeństwa publicznego, wymiaru sprawiedliwości, nadzoru oraz innymi powiązanymi zagadnieniami” na „kieruje i zarządza sprawami cywilnymi, bezpieczeństwa publicznego, wymiaru sprawiedliwości oraz innymi powiązanymi zagadnieniami”. Tym samym z kompetencji Rady Państwowej usunięto kierowanie i zarządzanie sprawami nadzoru.

14. W art. 100, który przyznaje lokalnym zgromadzeniom ludowym w prowincjach, miastach wydzielonych podlegajacych bezpośrednio rządowi centralnemu oraz ich stałym komitetom uprawnienia do wydawania przepisów o zasięgu lokalnym, dodano ust. 2: „Lokalne zgromadzenia ludowe w miastach podzielonych na dzielnice oraz ich stałe komitety moga wydawać przepisy o zasięgu lokalnym, które nie mogą naruszać konstytucji ani innych ustaw, aktów administracyjnych oraz lokalnych przepisów odpowiednio prowincji lub regionów autonomicznych i powinny wchodzić w życie po zgłoszeniu i zatwierdzeniu przez stałe komitety zgromadzeń ludowych prowincji lub regionów autonomicznych".

15. Ustęp 2 art. 101 otrzymał brzmienie: „Lokalne zgromadzenia przedstawicieli ludowych na szczeblu lub powyżej szczebla powiatu wybierają i mają prawo do odwołania przewodniczących komisji nadzoru, prezesów sądów ludowych i głównych prokuratorów prokuratur ludowych równego szczebla. Wybór lub odwołanie głównych prokuratorów z prokuratur ludowych muszą być zgłoszone głównym prokuratorom z prokuratur ludowych wyższego szczebla celem przedłożenia do zatwierdzenia stałym komitetom lokalnych zgromadzeń przedstawicieli ludowych odpowiednio wyższego szczebla".

16. W art. 103 ust. 3 dodano zakaz dotyczący łączenia funkcji członków stałego komitetu lokalnych zgromadzeń przedstawicieli ludowych i członków organów nadzoru: „Nikt ze stałego komitetu lokalnych zgromadzeń przedstawicieli ludowych na szczeblu lub powyżej szczebla powiatu nie może sprawować urzędu w państwowych organach administracyjnych, nadzoru, sądowych i prokuratorskich". 
17. W art. 104 dodano zapis o nadzorowaniu prac komisji nadzoru przez stałe komitety lokalnych zgromadzeń ludowych: „Stałe komitety lokalnych zgromadzeń przedstawicieli ludowych na szczeblu lub powyżej szczebla powiatu omawiają najważniejsze kwestie we wszystkich dziedzinach działalności w swoich jednostkach administracyjnych i decydują o nich, nadzorują pracę rządu ludowego, komisji nadzoru, sądu ludowego i prokuratury ludowej na równym szczeblu, uchylają nieprawidłowe decyzje i zarządzenia rządów ludowych równego szczebla, uchylają nieprawidłowe uchwały lokalnych zgromadzeń przedstawicieli ludowych niższego szczebla, decydują o powołaniu bądź odwołaniu funkcjonariuszy organów państwowych w granicach swoich kompetencji określonych ustawą i w okresie między sesjami lokalnych zgromadzeń przedstawicieli ludowych równego szczebla, odwołują indywidualnych deputowanych do lokalnych zgromadzeń przedstawicieli ludowych wyższego szczebla i wybierają deputowanych do obsadzenia wakatów w tym lokalnym zgromadzeniu przedstawicieli ludowych".

18. W art. 107 ust. 1 usunięto uprawnienie nadzorcze stałych komitetów lokalnych zgromadzeń przedstawicieli ludowych w sprawach dotyczących komisji nadzoru. Nowe brzmienie: „Lokalne zgromadzenia przedstawicieli ludowych na szczeblu lub powyżej szczebla powiatu, w granicach kompetencji, prowadzą działalność administracyjna w dziedzinach: gospodarki, edukacji, nauki, kultury, zdrowia publicznego, kultury fizycznej, rozwoju obszarów miejskich i wiejskich, finansów, spraw cywilnych, bezpieczeństwa publicznego, spraw narodowościowych, wymiaru sprawiedliwości i planowania rodziny. W odpowiednich jednostkach administracyjnych wydaja decyzje i zarządzenia, powołują lub odwołuja funkcjonariuszy administracyjnych, szkolą ich, oceniają ich wydajność i nagradzają ich lub karzą.

19. W rozdziale III Konstytucji ChRL wprowadzono nowy dział dotyczący komisji nadzoru. Dodano 5 artykułów:

Dział 7. Komisje nadzoru

Artykuł 123

Komisje nadzoru Chińskiej Republiki Ludowej na różnych szczeblach są organami nadzoru państwa.

Artykuł 124

Chińska Republika Ludowa ustanawia Państwową Komisję Nadzoru i lokalne komisje nadzoru różnych szczebli. Komisja nadzoru składa się z: przewodniczącego, kilku wiceprzewodniczących i kilku członków. Kadencja przewodniczącego komisji nadzoru jest taka sama jak kadencja lokalnego zgromadzenia przedstawicieli ludowych tego samego szczebla. Przewodniczący Komisji Nadzoru nad Państwem może pełnić swoją funkcję nie dłużej niż przez dwie kolejne kadencje. Organizację, funkcje i uprawnienia komisji nadzoru określa ustawa. 
Artykuł 125

Najwyższym organem nadzoru jest Państwowa Komisja Nadzoru Chińskiej Republiki Ludowej. Państwowa Komisja Nadzoru kieruje pracami komisji nadzoru na różnych szczeblach lokalnych, a komisje nadzorcze wyższych szczebli kieruja pracami komisji niższych szczebli.

Artykuł 126

Państwowa Komisja Nadzoru jest odpowiedzialna przed Ogólnochińskim Zgromadzeniem Przedstawicieli Ludowych i jego Stałym Komitetem. Komisje nadzoru na różnych szczeblach lokalnych są odpowiedzialne przed organami władzy państwowej, które je powołały i komisjami nadzoru wyższych szczebli.

Artykuł 127

Komisje nadzoru sprawują funkcje nadzoru niezależnie, zgodnie z przepisami prawa, i nie podlegaja ingerencji jakiegokolwiek organu administracyjnego, organizacji publicznych lub jednostek. Organy nadzoru, rozpatrując sprawy niezgodnego z prawem lub noszącego znamiona przestępstwa nadużywania władzy publicznej, będą z sobą współpracować i wzajemnie ograniczać się do zakresu swoich kompetencji z sądami, prokuraturami i organami ścigania.

Dotychczasowy dział 7 Sądy ludowe i prokuratury ludowe został zmieniony na 8, a art. 123-138 zyskały nową numerację - art. 128-143.

\section{Znaczenie i skutki zmian Konstytucji ChRL z 11 marca 2018 r.}

Po wprowadzeniu myśli Xi Jinpinga jako jednego z fundamentów chińskiej ideologii państwowej teorie przewodniczącego Xi stały się oficjalną doktryną Państwa Środka, a przewodniczący ChRL stał się pierwszym od czasów Mao Zedonga przywódca, którego idee wpisano do ustawy zasadniczej za życia ich autora. Od momentu najnowszej nowelizacji Konstytucji ChRL władze państwowe dążą do rozpowszechnienia teorii Xi Jinpinga wśród obywateli. Koncepcje Xi są również odrębnym przedmiotem akademickim na chińskich uniwersytetach'. Żaden inny chiński przywódca poza Mao Zedongiem nie miał tak silnej promocji w środowisku naukowym. Naukowcy, którzy prowadzą badania związane z filozofią Xi, mogą liczyć na wsparcie finansowe ze strony państwa ${ }^{10}$.

\footnotetext{
9 Np. Shaanxi University, Tsinghua University.

10 Instytut Pekiński Myśli Xi w 2018 r. miał budżet w wysokości 16 mln CNY (według Pekińskiej Federacji Nauk Społecznych). Naukowcy, którzy ubiegają się o finansowanie za pośrednictwem centrum, mogą uzyskać od 80 tys. do 300 tys. CNY na projekty; https://www.reuters.com/
} 
Koncepcje Xi Jinpinga dotyczą następujących zagadnień: socjalizm o chińskiej specyfice, realizacja „chińskiego marzenia” - odrodzenie narodu chińskiego, kompleksowe i pogłębione reformy, rozwój gospodarczy, państwo prawa, Chiny zaawansowane kulturowo, przedsięwzięcia socjalne, postęp w dziedzinie ekologii, obrona narodowa, ,jeden kraj, dwa systemy”, pokojowy rozwój, nowy model stosunków pomiędzy największymi mocarstwami, stosunki dyplomatyczne z sąsiadami, współpraca z krajami rozwijającymi się, stosunki wielostronne, ścisłe więzi ze społeczeństwem, zwalczanie korupcji, kierownicza rola $\mathrm{KPCh}^{11}$.

Należy zaznaczyć, że dodane w nowelizacji sformułowania, dotyczące m.in. „socjalizmu o chińskiej specyfice dla nowej ery”, ekologii, odrodzenia się narodu chińskiego czy harmonii, stanowią element myśli wygłaszanych przez Xi Jinpinga. Zmiany w Konstytucji ChRL potwierdzają filozofię rozwoju naukowego oraz kierowanie się ideologią socjalistyczną o chińskiej specyfice w polityce narodowej i życiu społecznym w erze Xi Jinpinga. Pozostałe zmiany w preambule stanowią konsekwencję wskazania myśli przywódcy jako podstawy ideologii państwowej.

Zdanie dodane w art. 1 Konstytucji ChRL: „Cechą definiującą socjalizm o chińskiej specyfice jest przywództwo Komunistycznej Partii Chin” - stanowi legitymizację władzy partii ${ }^{12}$. Do tej pory odniesienie do przywództwa Komunistycznej Partii Chin (KPCh) znajdowało się jedynie w preambule Konstytucji, której charakter jest przedmiotem pogłębionego dyskursu naukowego. Tym samym po raz pierwszy dokonana została konstytucjonalizacja władzy partii.

Do tej pory władza administracyjna ludu była reprezentowana przez organy państwowe. Władza polityczna narodu jako całości wyrażała się natomiast poprzez KPCh. Reprezentacyjny charakter partii w chińskim konstytucjonalizmie przebiegał w dwóch kierunkach. Zobowiązywał KPCh do przestrzegania ram normatywnych organizacji życia politycznego wyrażonych w samej Konstytucji ChRL. KPCh służyła również jako najwyższy wykonawca politycznych zasad, na których opiera się państwo, sprawując de facto faktyczną władzę w Chinach. Struktury zapewniające tę wierność były ważnym tematem debaty konstytucyjnej ${ }^{13}$. Od dawna poszukiwano rozwiązania umożliwiającego legitymizację władzy KPCh i jej formalne umiejscowienie w chińskim porządku konstytucyjnym. Dokonana zmiana usankcjonowała przywództwo tej partii jako jedynej siły politycznej liczącej się w Państwie Środka.

W zmienionej konstytucji znalazł się również obowiązek składania publicznie przez urzędników państwowych przysięgi konstytucyjnej po objęciu urzędu. Celem

article/us-china-politics-education/in-china-universities-seek-to-plant-xi-thought-in-minds-ofstudents-idUSKBN1JI0I5 (dostęp: 21.11.2018).

11 Zob. szerzej: Xi Jinping, Innowacyjne Chiny..., s. 21-416.

12 Szerzej o konieczności legitymizacji władzy KPCh zob. M. Dargas, Idee i zasady konstytucyjne..., s. 302-311.

13 Ibidem, s. 309; szerzej o instytucjonalizacji chińskiej konstytucji w układzie państwo - KPCh zob. s. $308-311$. 
tej zmiany jest kształcenie i motywowanie urzędników, aby byli lojalni wobec konstytucji, przestrzegali jej oraz szanowali i chronili jej autorytet.

Ponadto dodano ustęp dotyczący lokalnej władzy ustawodawczej. Przyznano możliwość wydawania przepisów lokalnych miastom podzielonym na dzielnice. Zapis dotyczący konieczności zatwierdzania przepisów przez stałe komitety lokalnych zgromadzeń przedstawicieli ludowych prowincji lub regionów autonomicznych ma na celu zapobieżenie rozproszeniu regulacji i tworzeniu tzw. prawa powielaczowego.

Doniosłe znaczenie ma również przyznanie komisjom nadzorczym statusu konstytucyjnego oraz powołanie Państwowej Komisji Nadzoru. Zmiana ta sankcjonuje reformę systemu nadzoru, co ma umożliwić instytucjom państwowym współpracę w działaniach antykorupcyjnych i wzmocnić scentralizowane przywództwo KPCh w tych działaniach. Państwowa Komisja Nadzoru jest tworzona przez OZPL i odpowiada przed nim. Kadencja przewodniczącego Państwowej Komisji Nadzoru jest taka sama jak kadencja OZPL i nie może przekraczać dwóch kolejnych kadencji. Państwowa Komisja Nadzoru jest najwyższym organem nadzorczym kierującym pracami komisji nadzoru wszystkich szczebli, a komisja nadzoru wyższego szczebla kieruje pracami podległej komisji nadzoru. Państwowa Komisja Nadzoru ma ścigać nadużycia pracowników instytucji państwowych (ok. $200 \mathrm{mln}$ osób) ${ }^{14}$.

Jedną z najważniejszych zmian w dotychczasowej Konstytucji ChRL jest zniesienie kadencyjności urzędu przewodniczącego i wiceprzewodniczącego Chińskiej Republiki Ludowej, co oznacza, że Xi Jinping będzie mógł rządzić dożywotnio, a jeśli nie, to przynajmniej do czasu wybrania swojego następcy. Uzasadnieniem dla tej zmiany miało być zapewnienie możliwości długoterminowego zarządzania krajem i długoterminowej stabilności władzy w partii i państwie. Należy przy tym zaznaczyć, że w Konstytucji ChRL w brzmieniu z 1982 r. wprowadzona została kadencyjność przewodniczącego ChRL, aby uniknąć skupienia pełni władzy w rękach jednego człowieka. Taki zapis w Konstytucji był bardzo istotnym postulatem Denga Xiaopinga, pełniącego funkcje przewodniczącego w latach 1978-1989. Powodem były wydarzenia związane z dyktatorskimi rządami Mao Zedonga, który sprawował władzę absolutną (rozumianą jako skupienie w rękach jednego człowieka trzech stanowisk: przewodniczącego ChRL, przewodniczącego Centralnej Komisji Wojskowej ChRL oraz przewodniczącego Komitetu Centralnego KPCh). W związku z tym Deng postulował, aby władza, zamiast należeć w pełni do jednego człowieka, zaczęła być traktowana w sposób kolektywny, co miało jednocześnie zapewnić

14 PKN będzie najprawdopodobniej sama inicjować postępowania i mieć pozasądowe prawo do zatrzymywania osób podejrzanych czy zamrażania ich środków finansowych. Pozostaje jednak podporządkowana KPCh. Nowy szef PKN, Yang Xiaodu, w hierarchii partyjnej stoi niżej od Zhao Leji, sekretarza Centralnej Komisji Inspekcji i Dyscypliny (CKID), tropiącej nadużycia w ramach KPCh, i jednocześnie podlega mu jako jego zastępca w CKID. Zob. M. Przychodniak, Znaczenie decyzji parlamentu XIII kadencji dla polityki ChRL, „Biuletyn PISM”, nr 50 (1623), 3.04.2018. 
płynność w wymianie kadr politycznych. Ten system funkcjonował sprawnie (wyłączając przekazanie władzy w latach 2002-2004). Nowelizacja Konstytucji ChRL, znosząca kadencyjność, ponownie umożliwia sprawowanie całości władzy jednej osobie. Jest to najbardziej komentowana w polskich i zachodnich mediach zmiana. Przy okazji tych komentarzy pojawiają się liczne porównania przewodniczącego Xi do Mao Zedonga ${ }^{15}$.

Należy zaznaczyć, że bardzo istotną zmianą z punktu widzenia chińskiego konstytucjonalizmu jest zmiana art. 70 Konstytucji. W drugim paragrafie zmieniono Komisję Prawną OZPL na Komisję Konstytucyjną i Prawną. Sygnalizuje to, że moga jej zostać nadane kompetencje do kontroli i interpretacji konstytucyjnej ${ }^{16}$.

Wprowadzone 11 marca 2018 r. zmiany w Konstytucji ChRL były pierwszymi od 14 lat. Wprowadzono wiele doniosłych poprawek, które dotyczą zagadnień już od dłuższego czasu pojawiających się w debacie naukowej i politycznej zarówno w Chinach, jak i na Zachodzie. Choć najbardziej komentowaną zmianą było zniesienie kadencyjności urzędu przewodniczącego ChRL, to z puntu widzenia rozwoju konstytucjonalizmu w Chinach najbardziej doniosła zmianą najprawdopodobniej okaże się umożliwienie Komisji Konstytucyjnej i Prawnej kontroli konstytucyjnej oraz interpretacji postanowień Konstytucji ChRL. Zmianą o bardzo istotnym znaczeniu z punktu widzenia chińskiego porządku konstytucyjnego jest także konstytucyjna legitymizacja władzy KPCh. Czas pokaże, jak w praktyce te zmiany wpłyną na kształtujący się konstytucjonalizm.

\section{SUMMARY}

\section{CHINESE CONSTITUTIONALISM - THE RECENT AMENDMENTS TO THE CONSTITUTION OF THE PEOPLE'S REPUBLIC OF CHINA}

The article presents the latest amendments to the PRC Constitution and their meaning in a wider context. In the first and second part of the article, the content of the PRC Constitution as worded before the amendment from March 2018 is presented. The third part focuses on the amendments introduced on 11 March 2018. The last part summarizes the most significant changes and points out the meaning of the changes for the Chinese legal system.

15 https://www.pap.pl/aktualnosci/news\%2C1324138\%2Cchiny-reforma-konstytucji-umacniawladze-xi-i-komunistow.html; https://www.independent.co.uk/news/world/asia/xi-jinping-chinacommunist-party-leader-president-national-peoples-congress-a8250426.html; https://www.theguardian.com/world/2018/feb/26/xi-jinping-china-presidential-limit-scrap-dictator-for-life (dostęp: 21.11.2018).

16 O potrzebie powołania specjalnego organu kontroli konstytucyjnej szerzej zob. M. Dargas, Idee $i$ zasady konstytucyjne..., s. 364-366. 